\title{
AMERICAN BUSINESS INTERESTS IN THE INDONESIAN REPUBLIC, 1946-1949
}

\author{
Gerlof D. Homan
}

Americans had little knowledge of prewar Indonesia, and most of the contemporary literature on that far-flung archipelago consisted of some travelogues and a few scholarly articles. ${ }^{1}$ Yet, many Americans were aware of the strategic and economic significance of this rich Dutch colonial possession. Thus American corporations, such as Standard Oil of New Jersey and US Rubber, had invested heavily in Sumatra, while General Motors and Goodyear had established factories on Java.

Total American investments in prewar Indonesia amounted to about 7 percent of all foreign investments, a not inconsiderable amount although small in comparison with British and Dutch investments. Furthermore, Americans purchased a large number of valuable commodities from Indonesia in the late $1930 \mathrm{~s}$, such as rubber, tea, quinine, etc. Thus, the United States received 48.7 percent of its latex, almost all of its quinine, 90 percent of its kapok, 84 percent of its palm oil, 80 percent of its its cigar wrappers, 96 percent of its tea, 74 percent of its copra, 81 percent of its raw green coffee, and some 8 percent of its tin from the Netherlands Indies. In 1939 the United States took about 20 percent of total Indonesian exports, a figure that increased to about 30 percent during the first two years of World War II. Total value of Indonesian export to the United States in 1939 was $\$ 92,971,000$; in 1941 this figure was $\$ 241,638,000 .^{2}$

The United States had never taken a very strong moral stand on the issue of colonialism except for a brief moment after the Spanish-American War and during the first two or three years of its involvement in World War II. Thus for some time after Pearl Harbor a few American statesmen, intellectuals, and others debated the future of European colonialism and recommended that the United States demand the emancipation of dependent peoples. Toward the end of the war most American statesmen concluded, however, that friendship and good relations with the European

1. John A. Sullivan, "The United States and the East Indies and World War II. American Efforts to Modify the Colonial Status Quo" (Ph.D. dissertation, Massachusetts Institute of Technology, 1969), pp. 70-71.

2. Ibid., p. 53; James W. Gould, Americans in Sumatra (The Hague: Nijhoff, 1961), passim; Jan O. M. Broek, Economic Development of the Netherlands Indies (New York: Institute of Pacific Relations, 1942), pp. 130-32; Glenn D. Babcock, History of the United States Rubber Company: A Case Study in Corporation Management (Bloomington, Ind.: Indiana University Bureau of Business Research, 1966), pp. $172 \mathrm{ff}$. ; Hugh Allen, The House of Goodyear: A Story of Rubber and Modern Business (New York: Corday \& Gross, 1943), passim; U.S. Department of Commerce, Bureau of the Census, Statistical Abstracts of the United States, 1942 (Washington, D.C.: Government Printing Office, 1943), p. 537; Peter M. Reed, "Standard Oil in Indonesia, 1898-1928," Business History Review, 32 (1958), pp. 311-37; The China Weekly Review, October 1939. 
colonial powers were more important than taking a strong moral stand on the issue of colonialism. Thus, in the postwar period the United States did little to pressure her wartime allies to grant immediate independence to colonial subjects. ${ }^{3}$ In the case of Indonesia the United States preferred to let Great Britain play the role of mediator between the Netherlands and the Indonesian Republic which had been proclaimed in August 1945. Later, from July 1947 until the end of 1949, the United States did intervene and urged the Netherlands to make substantial concessions. Especially in the period 1945-47, Washington advocated continuation of a strong Dutch presence in Indonesia which would be advantageous to the Netherlands and strengthen the Western alliance. Furthermore, a restoration of the Indonesian economy under Dutch auspices would be most advantageous to the world economy and the United States, which needed many of the valuable Indonesian commodities.

From August 1945 until July 1947 the Netherlands controlled only small enclaves on Java and Sumatra, the two most important islands of its Asian empire. The areas under Republican control during this period were the most productive of the archipelago. In order to prevent an outflow of many commodities from Republican-controlled areas to Singapore and elsewhere, the Netherlands imposed a blockade and on January 29, 1947, issued stringent export regulations. These regulations required export permits to be issued by the Netherlands Indies government's Department of Economic Affairs and forbade the export of so-called estate products. ${ }^{4}$ Yet, it was tempting to circumvent the Dutch blockade and establish contact with the Republic. Some American businessmen in particular concluded that perhaps they might miss the boat and not be able to share in a most lucrative trade with the Indonesian Republic. ${ }^{5}$ Also the Indonesian Republic was eager to trade with the outside world. Its economic condition was precarious, largely as a result of the Dutch blockade. It was felt that trade with the United States and a possible infusion of American capital would have a most beneficial effect on the Indonesian economy.

The first American business firm to establish contact with the Republic was the New York-based Isbrandtsen and Company, Inc., which concluded a contract with Yogyakarta in March 1947. By its terms Isbrandtsen would act as the Republic's commission merchant and carrier from Cheribon or Probolinggo to sell its commodi-

ties. Furthermore, Isbrandsten would act as the Republic's commission merchant to purchase American commodities with the proceeds of the sale of cargoes. For its services Isbrandsten would receive a commission of 5 percent.

The company vessel, the Martin Behrman, took on a large supply of "estate products" in Cheribon in February 1947, but it was seized by Dutch officials and brought to Batavia in early March, where its cargo was unloaded and confiscated. Isbrandtsen bitterly complained about this treatment and sent its representative, James Ryan, to Batavia in order to secure the restitution of the valuable cargo. Ryan, who quickly antagonized Dutch officials because of his arrogant and blustering behavior, failed to persuade the authorities to relent. The State Department, although decrying the new trade regulations, did support the Netherlands during

3. On this issue see Gerlof D. Homan, "The United States and the Indonesian Question, December 1941-December 1946," Tijdschrift voor Geschiedenis, 93 (1980), pp. 39-44.

4. S. L. van der Wal, ed., Officiële bescheiden betreffende de Nederlands-Indonesische betrekkingen, 1945-1950 (The Hague: Nijhoff, 1978), 1, pp. 79, 92, 689; Gerlof D. Homan, "The Martin Behrman Incident," Bijdragen en Mededelingen betreffende de Beschiedenis der Nederlanden, 90 (1979), pp. 253-54.

5. Homan, "Martin Behrman Incident," p. 254. 
this affair, which could have caused much anti-Dutch sentiment in the United States, where Isbrandtsen unsuccessfully attempted to arouse sympathy for his cause. Later, the State Department did assist the Company to reach a financial settlement with the Netherlands government in May $1949 .^{6}$

The second business venture with the Republic was undertaken by Leonard Weston. Before and during World War II, Weston worked for some technical firms and General Motors, and later he and others formed an industrial consultant firm. After Pearl Harbor, Weston served as lieutenant-colonel in the Army Air Force in the Pacific. In the fall of 1945 he was employed by the Foreign Economic Administration and sent to Indonesia on a relief and rehabilitation mission. Upon his return to the United States, he and his Dutch-born wife, Wilhemina van den Berg, a former sergeant of the Koninklijk Nederlands Indisch Leger [the Royal Netherlands Indies Army], gave various speeches and presentations in which they defended Dutch policies in Indonesia. In November Weston joined the Overseas Corporation, which represented a number of American companies that were interested in overseas investments. 7

Weston was very anxious to return to Indonesia to promote his company's business ventures as well as personal interests. But the Netherlands Indies government refused to grant him a visa. The Director of the Department of Economic Affairs; J. E. van Hoogstraaten, was vigorously opposed to Weston's reentry. Van Hoogstraaten felt that Weston was an "unreliable adventurer" who had deceived him during his previous visit by making false promises and representations. Allowing him to reenter, van Hoogstraaten pointed out, would not be in the national interest and would cause more trouble than that instigated by James Ryan. Yet Weston had good connections; and strong recommendations from N. A. C. Slotemaker de Bruine, director of the Netherlands Information Bureau of the Ministry of Foreign Affairs in The Hague, and even from the Dutch minister of foreign affairs, C. G. W. H. Boetzelaer van Oosterhout, finally made the authorities relent. ${ }^{8}$

Weston and his wife arrived in Batavia in late March 1947. Here van Hoogstraaten gave him a most unfriendly welcome and instructed other department heads not to communicate with him, an order that was later withdrawn. After reentering Batavia from Singapore in May of that year, Weston was invited by the Republican government to visit Yogyakarta. Weston was very enthusiastic over what he saw and concluded that the Republic was actually much stronger than the Dutch had been willing to admit. He saw no communist influence and found Sukarno and his ministers "extremely brilliant and clever." However, they did need experience and American support, he felt. Business should and could be done with the Republic, Weston informed his superiors, and he was happy to report that on May 6 he and Republican officials had drawn up a contract by which the Overseas Corporation would sell and buy commodities for the Republic at a fair price on the world market. For its services the Overseas Corporation would receive a commission of 2.5 percent of the value of all the goods exported and the same for commodities imported for the Republic. ${ }^{9}$

6. On the Martin Behrman incident, see ibid., pp. 253-70.

7. Gezantschap Washington [Washington Embassy], $\mathrm{K}-1 / 47.2$ Buitenlandse Zaken; Archief Ministerie van Buitenlandse Zaken, The Hague [hereafter cited as Archief $\mathrm{BZ}$.

8. Ibid.

9. Ibid. 
The Overseas Corporation was not too enthusiastic over the contract with the Republic, and it seemed the two transactions that took place in the next few months were principally between Weston and the Republic. In June 1947 the vessel Empire Tentagel shipped a large cargo consisting of rubber and quinine to Singapore. The cargo was sold, but the money was not deposited in the National City Bank of New York on behalf of the Republic. Another cargo, consisting of sugar and quinine, was shipped by the Empire Tenby in August 1947. It is not clear what happened to this cargo, but it is quite certain that the Republic did not receive payment for it. The first cargo might have been sold for as much as $\$ 330,000$ (Straits dollars) plus $\$ 263,000$. After these transactions, Weston considered it wise to leave Singapore, where he was wanted for falsification of documents while the contract with the Overseas Corporation was canceled by Sumitro as of December 31, 1947. 10

The Weston affair demonstrated the gullibility and lack of experience of the young Republic. Its officials, some of whom, according to Sumitro, had displayed an "irresponsible degree of lightheartedness," should have been much more cautious in their efforts to establish economic contacts with the outside world. ${ }^{11}$ On the other hand, Dutch officials were also taken in by what Stanley Hornbeck, the American ambassador to The Hague, called that "intriguer" Weston. ${ }^{12}$ In spite of various warnings by Netherlands Indies officials, The Hague felt that it owed the Westons something for their efforts to defend Netherlands policies in Indonesia. Could The Hague not have found better and more reliable individuals to influence American public opinion? During and after the Netherlands-Indonesian conflict, complaints were often voiced that much more could and should have been done by the Dutch government to influence American public opinion, because failure to explain the Netherlands' side of the conflict had resulted in adverse American policies. The issue of Dutch public affairs efforts in the United States 1945-49 merits further investigation; however, the choice of Weston does not speak well for whatever the Netherlands government saw fit to inform the American public The Hague was attempting to do in postwar Indonesia.

While the Weston affair did not create much negative reaction in the Netherlands, the Matthew Fox contract aroused much resentment and added to anti-American sentiment during 1948-49. The Fox contract, it was felt by many in the Netherlands, symbolized and embodied real American intentions to effect the decolonization of Indonesia. The ultimate American objective, it was contended, was to drive Dutch economic interest out of Indonesia to be replaced by Wall Street. ${ }^{13}$

In late December 1947 a lady in a hotel in Havana dropped a 37-page document that was picked up by a "friend of the Netherlands" who had it forwarded to the Dutch ambassador in Washington, E. van Kleffens. The document consisted of a contract drawn up between the Republic's financial and trade representative in New York, Sumitro Djojoadikoesoemo, and the well-known American businessman, Matthew Fox. The terms of the agreement called for the establishment of an AmericanIndonesian Corporation that would receive a monopoly on the sale of Republican

10. Ibid.; Archief van de Algemene Secretarie van Nederlands Indië, The Hague, II, 1071 .

11. Archief Algemene Secretarie, II, 1071.

12. Archief BZ K-1/47.2.

13. For some expressions of Dutch public opinion, see Haagsche Post, January 8 and March 12, 1949; Maasbode, January 27, 1949; Elsevier, July 24, 1948; U.S. Department of State, Foreign Relations of the United States [henceforth FRUS], 1949 (Washington, DC: Government Printing Office, 1975), 7, p. 429. 
commodities and the purchase of various consumer goods. For these services Fox would receive a commission of 7.5 percent for every ton moved. The corporation, which would be 51 percent American- and 49 percent Republican-owned, would also assist in the economic development and rehabilitation of Indonesia. Thus this contract was not unlike the agreements between the Republic and Isbrandtsen and Weston except that neither of the previous two contracts had provided for financial and technical assistance to rebuild the postwar Indonesian economy. Furthermore, this latest contract had been concluded with a highly respected American businessman. ${ }^{14}$

Matthew Fox was born in Racine, Wisconsin, in 1911 and worked as a theater manager, film buyer, and assistant to the president of Skouras Theatre Corporation before he became vice-president of Universal Pictures in 1937. Because of his considerable success in saving this company from bankruptcy, Fox became known as some kind of boy wonder of the American business world. During World War II Fox served on the War Planning Board and later in the US Army. He returned to Universal Pictures as executive vice president and also became chairman of the board of United World Films. In 1947 he resigned his $\$ 150,000$ position as executive vice president in order to be able to devote much of his time and energy to the newly founded American-Indonesian Corporation. ${ }^{15}$

Fox was imaginative, aggressive, dynamic, rather clever, and also somewhat of an idealist and romantic. Thus, although he undoubtedly hoped to be able to make a considerable profit from this new business venture, he was also sincerely interested in helping the Indonesian Republic in its struggle for independence. In this respect he was quite unlike Weston and Isbrandtsen. Furthermore, Fox had excellent contacts in the American business world and was in a position to attract a large amount of capital. Thus, van Kleffens was correct when he warned The Hague that Fox could not be easily written off and should be taken very seriously. ${ }^{16}$

How did Fox initiate his contacts with Sumitro? Apparently Fox was approached in November 1947 to help the Republic to honor an $\$ 80,000$ credit deposit in an American bank. Fox agreed to do so and subsequently suggested launching the AmericanIndonesian Corporation. ${ }^{17}$

Although the Netherlands government was undoubtedly tempted, it decided not to make public the information it had obtained concerning the Fox contract. Lieu-

14. K-1/47-16, Nederlands-Indië in de Veiligheidsraad IV; Gezantschap Washington $\mathrm{K}-1 / 47$, Matthew Fox Contract, Archief BZ. It is interesting to note that at the same time Sumitro negotiated and signed the contract with Fox he was conducting negotiations with two American oil companies, Superior Oil Company and the American Independent Oil Company. Archief Algemene Secretarie, II, 1071.

15. On Fox, see especially the intelligence gathered by the Netherlands Embassy in Washington, DC. Gezantschap Washington $\mathrm{K}-1 / 47.1$, Matthew Fox Contract, Archief BZ; Bill Davidson, "Fox of the Indies," Colliers, April 23, 1949, pp. 63-66; New York Times, June 3, 1964; John Coast, Recruit to Revolution: Adventure and Politics in Indonesia (London: Christophers, 1952), p. 283; Time, July 19, 1948, pp. 87-88.

16. Gezantschap Washington $\mathrm{K}-1 / 47.1$, Matthew Fox Contract, Archief BZ. On Fox's motives the author received further important information from Mr. Robert $R$. Nathan, former business partner of Fox. Mr. Nathan to the author, January 5, 1983.

17. Davidson, "Fox," p. 66. 
tenant Governor-General H. van Mook favored publication, but van Kleffens rightly feared that disclosure of the information would be exploited by the Soviet Union, which would promptly brand the contract as an American capitalistic plot to gain control over and subvert the Indonesian economy. ${ }^{18}$

Contrary to widely held public views in the Netherlands during the years 1948 1949 and even later, the State Department was very disturbed over the Fox contract and tried everything possible to thwart and discourage the venture. Fox and his associates, Robert Nathan and John Lee, were invited to the State Department, where they met officials on April 9, 1948, and were told that American-Republican trade would be a derogation of Netherlands sovereignty and might seriously disturb the delicate negotiations now in progress between the Netherlands and Yogyakarta. Furthermore, State Department officials stressed the monopolistic character of the contract. ${ }^{19}$

The State Department also instructed the American consul-general in Batavia, Charles Livengood, and the head of the American delegation of the United Nations Good Offices Committee, Coert duBois, to inform the Republic of Washington's opposition to the contract. Furthermore, State Department officials met with Sumitro on April 21 and told him during a three-hour meeting that the contract violated the International Trade Agreement Charter and the Renville agreement. Sumitro defended the contract by saying that his government had no confidence in the Netherlands. 20

In spite of State Department disapproval, Fox was undaunted and showed no desire to cancel the contract. Even after an unsuccessful business trip to Indonesia by representatives of Meyer and Brown, an American company in which Fox had considerable influence, to purchase commodities for the US Army-Navy Munitions Board he remained optimistic. ${ }^{21}$ Yet, in the summer of 1948 van Kleffens became afraid that Fox might do the Netherlands much harm if he were not seriously and properly handled. He was especially concerned that Fox might launch a press and radio campaign urging the discontinuation of ECA funds to the Netherlands. It was for these reasons that van Kleffens suggested a meeting with Fox. The Hague approved, and after a preliminary meeting with the Netherlands Indies trade representative, Emile Zimmerman, van Kleffens met Fox on June 14, 1948. Van Kleffens saw Fox as a man of "short, squat stature" and a typical representative of the Jewish race. Fox impressed the Netherlands ambassador as being serious and "competent" and, although he seemed interested in making a profit from his business venture, he also appeared anxious to make an important contribution to the economic reconstruction of Indonesia. Furthermore, Fox suggested to van Kleffens that a considerable portion of his profit be used to purchase commodities in the

18. Archief Algemene Secretarie, P. 2, 16; Gezantschap en Ambassade Washington $\mathrm{K}-1 / 48.4$, Onderhandelingen II, Archief $\mathrm{BZ}$.

19. Gezantschap Washington K-1/47.1, Matthew Fox Contract, Archief BZ; Department of State, FRUS, 1948 (Washington, DC: Government Printing Office, 1974), 6, pp. 151-52; FRUS, 1949, 7, pp. 589-90.

20. Department of State, FRUS, 1948, 6, pp. 155-56; Indonesië 912.1; Gezantschap Washington $\mathrm{K}-1 / 47.1$, Matthew Fox Contract; Gezantschap Washington $\mathrm{K}-1 / 48.4 .1$, Onderhandelingen II, Archief BZ.

21. On this business trip see especially Gezantschap Washington $\mathrm{K}-1 / 47.1$, Matthew Fox Contract, Archief BZ. 
Netherlands. Finally, Fox even indicated a willingness to go to The Hague to negotiate with officials there. The Dutch government indicated a few weeks later that it was willing to meet with Fox, and on August 20 Emile Zimmerman extended to him a formal invitation to go to The Hague to discuss his "projected operations" in parts of Indonesia. However, to the best of my knowledge no such meeting ever took place. ${ }^{22}$

In the meantime, much of the content of the contract had become known. Republican papers referred to the matter, and in early July D. U. Stikker, the future Netherlands foreign minister, commented on it rather extensively in an interview with the Algemeen Handelsblad. ${ }^{23}$ General public opinion in the Netherlands, at that time and especially after the so-called Second Police Action of December 1948, was most negative. Somehow, in spite of State Department efforts to discourage the Fox contract, Dutch public opinion generally concluded that Washington and Wall Street had blessed the venture.

After the Second Police Action of December 1948, Fox had little opportunity to gather any substantial profits. Nor was he able to attract any outside American capital. Whatever capital was invested in the undertaking must have been his own and might never have been repaid. It is difficult to determine how much Fox invested in the Indonesian venture. Perhaps at least $\$ 550,000$ was given or "loaned" to the Republic, much of which was used to finance the Indonesian UN mission in New York. Furthermore, Fox might have spent some $\$ 215,000$ to establish a socalled propaganda fund and paid $\$ 140,000$ for two second-hand C-54 airplanes. ${ }^{24}$

Already in early 1949 Fox expressed a desire to withdraw from the AmericanIndonesian corporation and to annul the contract. In March 1950, shortly after the Republic gained sovereignty, the Indonesian government cancelled the contract and Fox expressed no regrets. ${ }^{25}$

The Fox contract was not a Wall Street capitalistic plot to secure a large portion of Indonesia's fabulous wealth. It was a business undertaking by a clever but also somewhat idealistic and naive American businessman who thought he could secure a good profit and at the same time make a substantial contribution to Indonesian independence. Neither one of his expectations was realized. Fox did not gain materially, and his contributions to Indonesia's independence were minimal. He was not a modern "American Lafayette" nor the "economic god-father" of the Indonesian Republic, as he has sometimes been described. ${ }^{26}$

However, in a more subtle and indirect way the Fox contract did help the Republican cause. The Indonesians used Fox to further their own policies. They might have considered him a somewhat naive and romantic American who could be used to bolster their international position. Weston was correct when he wrote that the Republican officials lacked experience, and their contract with him and the agreement with the Isbrandsten Company might have taught them to be more cautious and more subtle.

22. Ibid. See also Achief Algemene Secretarie, P. 2, 16.

23. Gezantschap Washington K-1/47.1, Matthew Fox Contract, Archief BZ. See also Algemeen Handelsblad, July 1, 1948.

24. Ibid.; Davidson, "Fox," p. 63. Nathan agrees that Fox lost rather than gained from this venture. Mr. Nathan to author, January 5, 1983.

25. Department of State, FRUS, 1950 (Washington, DC: Government Printing office, 1976), 6, pp. 976, 919; New York Times, January 8 and March 24, 1950.

26. New York Times, June 3, 1964, p. 43; Davidson, "Fox," p. 63. 
The issue of foreign affairs had been one of the principal points of contention between the Netherlands and the Republicans during their lengthy and protracted negotiations from 1947 until late 1948. The Republic refused to surrender what it considered to be its sovereign right to conduct foreign relations with other nations, while the Netherlands insisted that the Republic should subordinate itself to an interim government during a transition period leading to independence. In 1948 the United States gradually shifted its strong pro-Netherlands position but supported the Dutch position as far as the issue of foreign affairs was concerned. Thus Washington, although tempted at times, had not recognized the Republic as a sovereign state. By the Fox contract the Republic achieved two objectives. It embarrassed and frightened the Dutch government, which feared the influence of a respectable businessman like Fox who might try and succeed in breaking the Dutch blockade. Furthermore, the Republic, while circumventing Washington, had established a valuable contact with the respectable American business world. Thus the Repub lic's international leverage had been increased. 